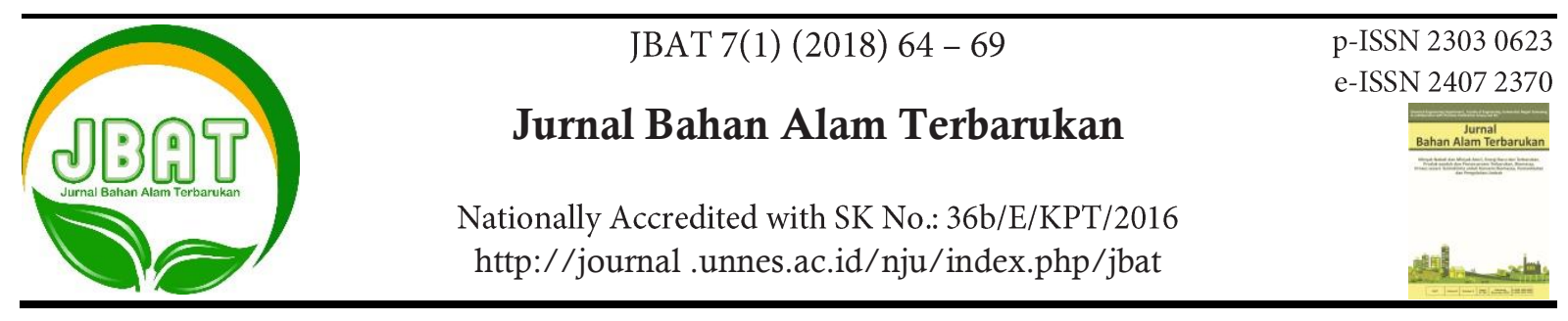

\title{
The Extraction of Brown Algae (Sargassum sp) Through Calcium Path to Produce Sodium Alginate
}

\section{Octovianus SR Pasanda ${ }^{\bowtie}$, Abdul Azis}

DOI 10.15294/jbat.v7i1.11412

Departement Chemical Engineering, Politeknik Negeri Ujung Pandang, Makassar, Indonesia, 90245

\begin{tabular}{|c|c|}
\hline Article Info & Abstract \\
\hline $\begin{array}{l}\text { Article history: } \\
\text { Received } \\
\quad \text { September } 2017 \\
\text { Accepted } \\
\quad \text { October } 2017 \\
\text { Published } \\
\quad \text { June } 2018 \\
\text { Keywords: } \\
\text { Brown algae; } \\
\text { Sodium alginat; } \\
\text { Sargassum sp; } \\
\text { Extraction }\end{array}$ & $\begin{array}{l}\text { Brown algae is a source of sodium alginat raw material. One type of brown algae that is found } \\
\text { to grow in Indonesian waters is Sargassum echinocarphum. Brown algae including one type of } \\
\text { seaweed that grows in many waters of Indonesia, especially the waters of Eastern Indonesia. } \\
\text { Alginat is a pure polysaccharide of uronic acid contained in a brown algae cell wall arranged } \\
\text { in the form of long linear chain alginic acids with levels reaching } 40 \% \text { of the total dry weight. } \\
\text { The alginat form in general is sodium alginat, a water soluble alginat salt. The purpose of this } \\
\text { research is to know the quality of alginat include alginat rendamen, water content, ash } \\
\text { content, and viscosity. Conventional extraction methods from brown algae into sodium } \\
\text { alginat produces the highest yield percentage of } 32.42 \% \text {, resulting from the extraction for } 7 \\
\text { hours at } 60^{\circ} \mathrm{C} \text {. The lowest average yield percentage resulted in } 5 \text { hours extraction process of } \\
2.78 \% \text {, the average water content of } 20.37-23.30 \% \text {, the mean ash content of } 22.28-34.87 \% \text {, } \\
\text { and the viscosity ranged between } 18.0-19.8 \mathrm{Cp} \text {. }\end{array}$ \\
\hline
\end{tabular}

*This article is a revised and extended version which had been presented at SNTK UNNES 2017, Semarang,

Indonesia, September 20 2017.

\section{INTRODUCTION}

One of the potential marine biota of Indonesian waters is the macro algae, known in trade as seaweed. These marine macro algae do not have roots, stems and leaves which are then called thallus, therefore taxonomically grouped into Divisio Thallophyla. Four major classes in the divisio are Chlorophyceae (green algae), Phaehphyceae (brown algae), Rhodophyceae (red algae), and Cyanophyceae (blue-green algae) (Waryono, 2001). Macroalgae including red, green, and brown algae are commonly referred to as seaweed (Castro \& Huber, 2009). Brown seaweed has a pigment that gives a brown color and can produce algin or alginate, laminarin, cellulose, ficoidin and mannitol whose composition is highly dependent on species, developmental period and place of growth
(Maharani \& Widyayanti, 2009). The main component of algae is carbohydrates while the other components are protein, fat, ash (sodium and potassium) and water $80-90 \%$ (Chapman \& Chapman, 1980).

Alginate is a pikokoloid compound produced from brown seaweed (Phaeophyceae) that Macrocytis, Laminaria, Aschophyllum, Nerocytis, Eklonia, Fucus, Turbinaria and Sargassum (Zailanie et al., 2001). Alginofit seaweed species found in Indonesian waters are Sargassum and Turbinaria (Zailanie et al., 2001). Alginate content in seaweed Sargassum ranges between $8-32 \%$ depending on the conditions of the waters where it grows (Anggadireja et al., 1993).

Alginate is one of the polysaccharide groups that is a major component of brown algae sap and is an important compound in cell walls

(C) 2017 Semarang State University

\footnotetext{
${ }^{\square}$ Corresponding author:

Departement Chemical Engineering, Politeknik Negeri Ujung Pandang,

Makassar, Indonesia, 90245

E-mail: o.pasanda@yahoo.com
} 
(Belitz \& Grosch, 1982; Kloareg \& Quatrano, 1988). In the cell wall and the intercellular environment, alginate is found as a mixture of alginic acid salts (calcium, sodium or potassium). Chemically, alginate is a pure polymer of uronic acid composed of long linear alginic acid (Stephen, 1995). This pure polymer is unbranched and contains $1.4 \beta$ D-mannuronic acid bonds and $1.4 \alpha$ L-guluronic acid bonds. The alginate form is generally a sodium alginate, the alginate salts are soluble in water. Other water-soluble alginate forms are potassium alginate or ammonium alginate, whereas the water-insoluble alginate is calcium alginate. Sodium alginate has colloidal, gelforming, and hydrophilic properties causing this compound widely used as emulsifier and stabilizer in industry (Subaryono, 2010). While the nature of hydrophilic alginate used to bind water to the process of freezing food. In frozen foods, this polymer maintains a food network. In addition, alginates are also utilized in the cosmetic, biomedical, pharmaceutical and widely used in various industrial fields, including textiles, paper, due to their water-binding properties such as gel, viscosity and dispersion stabilization (Draget et al., 2006).

The purpose of this research was to study the effect of temperature and duration of extraction to the yield of sodium alginate by conventional method. Furthermore, know the characteristics of the resulting Sodium alginate, consisting of water content, ash content and viscosity extract.

\section{RESEARCH METHODOLOGY}

Sodium alginate extraction procedure is carried out as follows: Brown seaweed (Sargassum $s p$ ) collected on Jeneponto beach. This biomass is washed with water, then dried with direct sunlight. The extraction was performed in accordance with Calumpong et al. method (1999) with some minor improvements of the method. The sample was dried to constant weight at $60^{\circ} \mathrm{C}$ in the oven, soaked for 24 hours in a solution of formaldehyde $2 \%$ (1:30 $\mathrm{w} / \mathrm{v})$ to remove the pigment thus simplifying the process of formation of alginic acid, then washed with distilled water and then soaked again in a solution of $\mathrm{HCl}$ 0,2 $\mathrm{M}(1: 30 \mathrm{w} / \mathrm{v})$ for 24 hours. After this period, the sample was washed once again with aquades until neutral. The next process is done by reference to the work of Torres et al. (2007) with a few minor modifications, adding $2 \% \mathrm{Na}_{2} \mathrm{CO}_{3}(1: 10$ $\mathrm{w} / \mathrm{v}$ ), stirred for 5 hours. To determine the effect of temperature then extraction is done at different temperature $\left(50^{\circ} \mathrm{C}\right.$ and $\left.60^{\circ} \mathrm{C}\right)$, then filtered through muslin cloth. The filtrate is aerated for 3 hours, and the clear bottom is removed. The filtrate was added $\mathrm{CaCl}_{2} 0.5 \mathrm{M}$ to form calcium alginate fibers are then added technical $\mathrm{NaOCl} 0.1 \%(1: 10 \mathrm{w} / \mathrm{v})$ for bleaching. Soaked in $0.5 \mathrm{M} \mathrm{HCl}$ solution $(1: 10 \mathrm{w} / \mathrm{v})$ for calcium alginate to be converted to alginic acid. Reduction of the water content of alginate acid gel is by pressing up to its moisture content of about $25 \%$. The sodium carbonate powder is then added in the mixer so that the alginate acid gel is converted to sodium alginate in paste form and then immersed in technical ethanol, dried in the sun for \pm 12 hours until the water content of $12 \%$. Furthermore, crushed and analyzed for levels of sodium alginate using AOAC method (1995), the water content and viscosity value using Brookfield Viscometer.

\section{Processing Technique and data analysis Water content (AOAC, 1984)}

Drying of the sample is carried out for several hours at a temperature of $105^{\circ} \mathrm{C}$ to a constant sample weight.

$$
\text { Water content }(\%)=\{\mathrm{Wo}-\mathrm{W} 1) / \mathrm{Wo}\} \times 100 \%
$$

where $\mathrm{Wo}_{0}$ is initial sample weight and $\mathrm{W}_{1}$ is sample weight after drying.

\section{Ash content (AOAC, 1984)}

The ash content test was carried out as follows: Porcelain cup was dried in the oven for 1 hour at $105^{\circ} \mathrm{C}$, then cooled in desiccator and weighed to obtain a constant weight (A). Weigh a few grams of sample (B), inserted in a porcelain dish, then put in a furnace with a temperature of $650^{\circ} \mathrm{C}$ for \pm 5 hours. The porcelain cup is then cooled for 30 minutes in the desiccator, then weighed until to obtain the constant weight (C).

Ash content $(\%)=[(\mathrm{C}-\mathrm{A}) / \mathrm{B}] \times 100 \%$

\section{Viscosity (AOAC, 1984; FMC Crop., 1997)}

$1.5 \%$ alginate solution is heated in a boiling water bath while stirring regularly to $75^{\circ} \mathrm{C}$. Viscosity was measured using Brookfield Viscometer model LVP with spindle 3 at a speed of $30 \mathrm{rpm}$. 
Table 1. Yield percent of Sodium Alginate conventional extraction results

\begin{tabular}{ccccc}
\hline $\begin{array}{c}\text { Brown Algae } \\
\text { mass } \\
(\text { gram) }\end{array}$ & $\begin{array}{c}\text { Temperature } \\
\left({ }^{\circ} \mathbf{C}\right)\end{array}$ & $\begin{array}{c}\text { Extraction } \\
\text { Time } \\
\text { (h) }\end{array}$ & $\begin{array}{c}\text { Na-Alginat } \\
\text { mass } \\
\text { (gram) }\end{array}$ & $\begin{array}{c}\text { Yield } \\
(\%)\end{array}$ \\
\hline 80.19 & 50 & 5 & 2.23 & 2.78 \\
80.07 & 50 & 6 & 4.52 & 5.65 \\
80.04 & 50 & 7 & 7.34 & 9.18 \\
80.10 & 60 & 5 & 17.41 & 21.73 \\
80.12 & 60 & 6 & 20.02 & 24.99 \\
80.08 & 60 & 7 & 25.96 & 32.42 \\
\hline
\end{tabular}

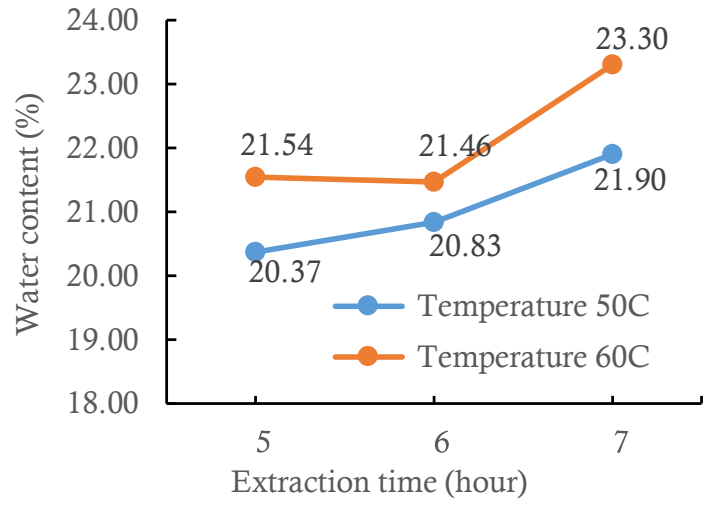

Figure 1. The water content of sodium alginate by conventional method

\section{RESULTS AND DISCUSSION}

The research was conducted by experiment of brown seaweed extract conventionally (through calcium alginate) with 5,6 , and 7 hours extraction time variables at 50 and $60^{\circ} \mathrm{C}$ respectively.

The alginate extraction process is carried out by converting alginic acid to sodium alginate having water soluble properties using $2 \% \mathrm{Na}_{2} \mathrm{CO}_{3}$ solution as stated by Helmiyati and Aprilliza (2017) that extraction using $\mathrm{Na}_{2} \mathrm{CO}_{3}$ (sodium carbonate) is capable of separating the cellulose and alginate present in brown algae cells. After the depigmentation process and the removal of fat sequentially with $2 \%$ formalin and $0.2 \mathrm{M} \mathrm{HCl}(1: 30$ $\mathrm{w} / \mathrm{v}$ ) for 24 hours at $30^{\circ} \mathrm{C}$ under constant stirring, the average sodium alginate yield as shown in Table 1.

\section{Percent Yield of Sodium Alginate}

Table 1 shows that the longer the extraction time and temperature the greater the sodium alginate also increases. This is because in the extraction process there are several things that affect, one of which is the contact time between the solvent with brown seaweed. The longer the contact

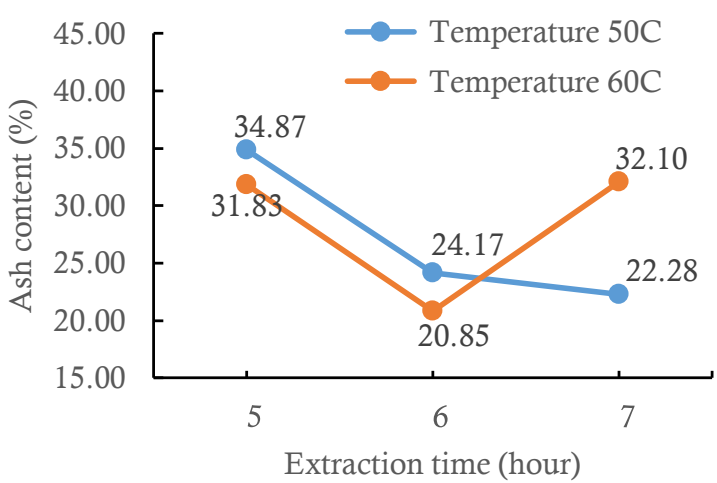

Figure 2. The ash content of Natrium Alginat by conventional method

time then the solvent will have a longer chance to dissolve all the alginate content contained in the brown seaweed cell. Another factor is that with the treatment at a greater temperature, the yield of sodium alginate is also greater, this is because if the temperature increases then the frequency of collisions between molecules is also increased so that more easily penetrated by the solvent (Pasanda et al., 2016). According to Fertah et al. (2017), with rising temperatures, the degradation occurring in macromolecular chains is also greater. However, the alginate content in brown seaweed is also affected by several parameters such as age, species and habitat of brown seaweed (Taylor, 1979). Characterization of sodium alginate was done to find out the physical and chemical properties of extracted sodium alginate which include analysis of water content, ash content, viscosity, and structural analysis.

\section{Water content analysis}

The water content of sodium alginate extracted can be seen in Figure 1. Based on the result of the research shows that the extracted sodium alginate water content is much greater when compared to Food Chemical Codex standard 


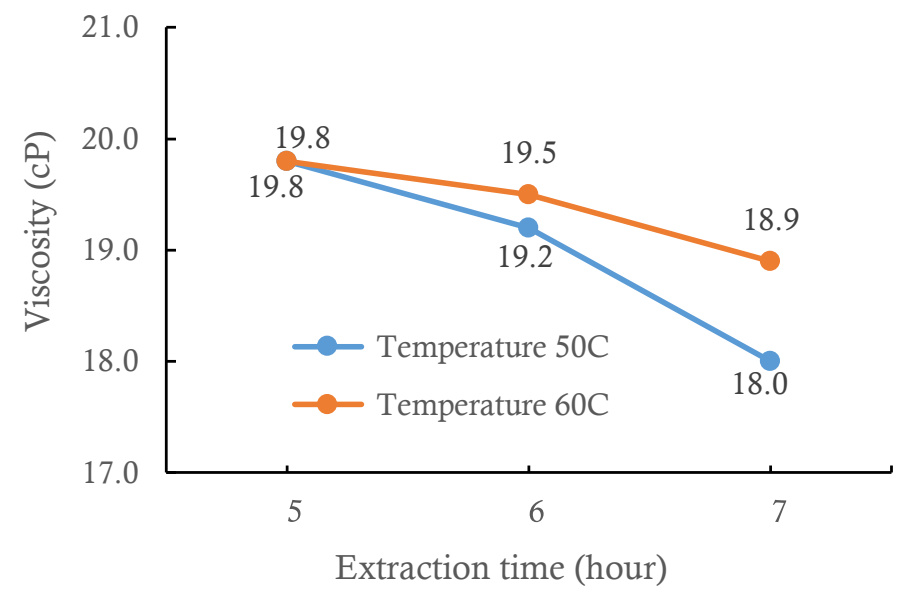

Figure 3. Viscosity of Sodium Alginate Solution (1\% Na-alginate in water)

(1993), where the water content of sodium alginate according to Food Chemical Codex (FCC) is not more than $15 \%$.

This is due to the use of ethanol as a sodium alginate extract wash less water. Ethanol polarity that has polar properties approaching water makes it more difficult to attract water.

\section{Ash Content}

The ash content of sodium alginate extracted by conventional method can be seen in Figure 2. The results obtained are ash content of sodium alginate is still much greater when compared with the standard according to Food Chemical Codex (FCC) is $<15 \%$. The results obtained are ash content of sodium alginate is still much greater when compared with the standard according to Food Chemical Codex (FCC) is $<15 \%$. While the specification of sodium alginate for food by $23 \%$ (Chapman \& Chapman,1980). So some treatment when compared with the conditions according to Chapman \& Chapman (1980), still qualified.

\section{Viscosity}

Viscosity is a parametric quality of Naalginate which is very necessary because the assessment of Na-alginate is determined by the high viscosity. The viscosity value of sodium alginate extracted by conventional method as in Figure 3 ranged from $18.0-20.4 \mathrm{cP}$. The trading standards established by Sigma (1997) for viscosity $\mathrm{Na}$ alginate were divided into three groups of quality that is grade I (high grade) viscosity of $14,000 \mathrm{cP}$, grade II (medium grade) viscosity of $3500 \mathrm{cP}$, grade III (low grade) viscosity of $250 \mathrm{cP}$. Meanwhile, according to Winarno (1990), the viscosity of Naalginate is very varied i.e. from $10-5000 \mathrm{cP}(1 \%$ solution of Na-alginate in water). When compared with the standard Na-alginate determined by Sigma, the Na-alginate produced from this study has not entered criteria I, II, or III (low grade). The viscosity of Na-alginate is highly dependent on the age of harvest of brown seaweed, extraction technique (concentration, temperature, $\mathrm{pH}$, and presence of polyvalent metal cations) and molecular weight of the seaweed extract (Basmal et al., 1998). The viscosity of the alginate solution will decrease due to overheating. On heating for too long will result in molecular degradation and subsequently lead to a decreased viscosity (Basmal et al., 1998; Murtini et al., 1998).

\section{CONCLUSION}

The results of the research concluded that the extraction of brown seaweed by conventional method produce sodium alginate with highest yield percentage of $32.42 \%$ with 7 hours extraction time at temperature $60^{\circ} \mathrm{C}$. The lowest percentage of yield produced in the extraction process for 5 hours was $2.78 \%$, the average water content of 20.37 $23.30 \%$, the average ash content of $22.28-34.87 \%$, and the viscosity ranged from $18.0-19.8 \mathrm{cP}$.

\section{ACKNOWLEDGEMENT}

This work was financially supported by Ministry of Technology Research and Higher Education of Indonesia that provide grant funds to conduct this research in 2017. 


\section{REFERENCES}

Anggadireja, J., Azatniko, W., Sujatmiko, Noor, I. 1993. Teknologi Produk Perikanan dalam Industri Farmasi, Dalam Stadium General Teknologi dan Alternatif Produk Perikanan dalam Industri Farmasi.

AOAC 1995. Official methods of analysis of the association of official analitycal chemist. Inc. Washington DC. 185-189.

Basmal, J., Yunizal, Tazwir. 1998. Pengaruh perlakuan pembuatan semi refined alginat dari rumput laut coklat (Turbinaria ornata) segar terhadap kualitas sodium alginat (in Indonesian). Prosiding Pra Kipnas VII. Forum Komunikasi I. Ikatan Fikologi Indonesia (IFI). Serpong, 8 September 1999. 97-110.

Belitz, H.D., Grosch, W. 1982. Food Chemistry. Springer Verlag Berlin Heidebberg New York, London, Paris, Tokyo

Calumpong, P.H., Maypa, P.A., Magbanua, M. 1999. Population and alginate yield and quality assessment of four Sargassum species in Negros Island, central Philippines. Hydrobiologia. 398:211-215.

Castro, P., Huber, M. 2009. Maryne Biology. New York Mc-Graw-Hill Companies Inc.

Chapman, V.J., Chapman. D.J. 1980. Seaweed and Their Uses. Third Edition. Chapman and Hall. London-New York.

Darmawan, M., Tazwir, Hak, N. 2006. Pengaruh Perendaman Rumput Laut Coklat Segar dalam Berbagai Larutan Terhadap Mutu Natrium Alginat. Buletin Teknologi Hasil Perikanan. Vol IX Nomor 1.

Draget, K.I., Moe, S.T., Skja ${ }^{\circ}$ k-Bræk, G., Smidsrød, O., 2006. Alginats. In: Stephen, A.M., Phillips, G.O., Wiliams, P.A. (Second Edition.). In: Food Polysaccharides and their Applications. CRC Press Boca Raton, Florida. 14:1591178.

FCC, 1993. Food Chemical Codex, National Academy Press Washington

Fertah, M., Belfkira, A., Dahmane, E.M., Taourirte, M. 2017. Extraction and characterization of sodium alginate from Moroccan Laminaria digitata brown seaweed. Arabian Journal of Chemistry. 10:S3707-S3714.
Helmiyati and Aprilliza, M. 2017. Characterization and properties of sodium alginate from brown algae used as an ecofriendly superabsorbent. International Symposium on Current Progress in Functional Materials. IOP Conf. Series: Materials Science and Engineering 188, 012019

Kloareg, B., Quatrano, R.S. 1988. Structure of the cell walls of marine algae and ecophysiological functions of the matrix polysaccharides. In: Oceanography and Marine Biology: An Annual Review. Aberdeen University Press/Allen \& Unwin: London. 26:259-315.

Maharani, M.A., Widyayanti, R. 2009. Pembuatan alginat dari rumput laut untuk menghasilkan produk dengan rendamen dan viskositas yang tinggi. In: Seminar Tugas Akhir S1 Teknik Kimia UNDIP 2009. Universitas Diponegoro. Indonesia.

Murtini, J.T., Basmal, J., Yunizal. 1998. Pengaruh pemucatan dan $\mathrm{pH}$ filtrat terhadap mutu natrium alginat. Dalam Laporan teknis penelitian. Penelitian teknologi ekstraksi alginat dari rumput laut coklat (Phaeophyceae). Instalasi Penelitian Perikanan Laut Slipi. Jakarta. 93 - 98.

Pasanda, O.S.R., Azis, A., Kusuma, H.S. 2016. Utilization of Waste Seaweed through Pretreatment with Liquid Hot Water Method and Simultaneous Fermentation using Bacteria Clostridium thermocellum. Journal of Materials and Environmental Science. 7(7):2526-2533

Sigma Chemical Co. 1997. Biochemicals and Reagents for Life Science Research, St. Louis, MO. 740

Stephen, M. (1995). "Food Polysaccharide and Their Applications". Departement of Chemistry. University of Cape Town Rondebosch. South Africa.

Subaryono, 2010. Modifikasi Alginat Dan Pemanfaatan Produknya. Squalen. 5(1):17.

Taylor, W.R. 1979. Marine Algae of The Eastern Tropical and Subtropical Coasts of the Americas. The University of Michigan Press.

Torres, M.R., Sousa, A.P.A., Filho, E.A.T.S., Melo, D.F., Feitosa, J.P.A., de Paula, R.C.M., Lima, M.G.S., 2007. Extraction and physicochemical characterization of 
Sargassum vulgare alginate from Brazil. Carbohydrate Research. 342:2067-2074.

Waryono, T. 2008. Biogeografi Alga Makro (Rumput) Laut di Kawasan Pesisir Indonesia. Makalah dalam Seminar Ikatan Geografi Indonesia (IGI) di Malang. Jurusan Geografi FMIPA. Universitas Indonesia. Jakarta.

Williams, A.R. 1983. Ultrasound: Biological Effects and Potential Hazards. Academic Press.
Winarno, FG. 1986. Kimia Pangan dan Gizi, Gramedia, Jakarta.

Zailanie, K., Susanto, T., Simon B.W. 2001. Ekstraksi dan Pemurnian Alginat dari Sargassum filipendula Kajian dari Bagian Tanaman, Lama Ekstraksi dan Konsentrasi Isopropanol. Jurnal Teknologi Pertanian. 2(1):10-27. 